Magdalena WierCIOCH

University of Rzeszow, Poland

\title{
The influence of the socio-demographic characteristics of the young on mobile telephone payment usage levels
}

\begin{abstract}
The study aims to determine the impact of high school students' socio-demographic characteristics from Podkarpackie Voivodeship on the level of use of modern forms of payment and banking services and to assess the security levels of these tools. The data was obtained through a survey where the research tool was a questionnaire conducted among students. The study of the literature on the subject and reports from other studies on similar topics were used. Research has shown that socio-demographic characteristics influence the level of use of some modern payment and banking services such as secure online payments, mobile applications for online shopping and electronic banking. Young male respondents expressed higher ratings for mobile banking security as well as for electronic payments. Similarly, the level of parents' education was associated with an increase in students' positive assessment of the security of mobile banking and electronic payments. The results suggest a need to increase financial knowledge and awareness among young people and their parents in modern forms of payment and banking services.
\end{abstract}

Keywords: electronic banking; electronic mobile payment; financial awareness; high school; students

Received: 3 November 2020

Accepted: 4 March 2021

\section{Suggested citation:}

Wiercioch, M. (2021). The influence of the socio-demographic characteristics of the young on mobile telephone payment usage levels. Przedsiębiorczość - Edukacja [Entrepreneurship - Education], 17(1), 234-243. https://doi.org/10.24917/20833296.171.18

\section{Introduction}

The development of electronic banking took place on a large scale at the end of the 20th century, completely changing the face of banking (Ahmed, Phin, 2016; Salehi, Alipour, 2010). Recent years have seen intensive development of financial services, including electronic services such as e-wallets related to the implementation of innovative solutions based on modern information technology. Consequently, technological progress enables access to an increasing number of financial products and services in the electronic form. Access to modern banking products and services has been significantly facilitated without the need to visit bank branches. Thanks to obtaining accurate information about 
customers, banks have the opportunity to adapt their offers to the individual preferences of their customers (Kisiel, 2011) while offering services to younger users.

According to the researchers, the level of electronic banking use among adults is related to socioeconomic characteristics such as age, gender, and residence (Czarnecki, 2017; Karjaluoto, Mattila, Pento, 2002; Munusamy, Chelliah, Annamalah, 2013).

The level of knowledge and financial awareness of Poles is the subject of numerous popular academic studies. One of the most recent, conducted in March 2019 at the request of the Warsaw Banking Institute (WIB) and the Warsaw Stock Exchange Foundation (FGPW), showed that young people aged 18-34 (57\%) rated their financial knowledge in the lowest categories. Also, research has shown that $49 \%$ of Poles (i.e. almost half of the population) stated that their knowledge of finance is 'low' or 'very low', while 'good' or 'very good' responses were given by only 9\% of citizens (Business Insider Polska, 2019).

A similar study was carried out by Maison \& Partners on behalf of the educational website Kapitalni.org. Among the various financial issues Poles were asked about, self-assessment of the level of knowledge and skills related to non-cash payments, bank cards, online payments and electronic money deserve special attention. This time, $24 \%$ of the respondents (second-highest result) stated that they have much knowledge of the subject, and 52\% that their level of knowledge is average (Business Insider Polska, 2018).

Such results encourage more profound research into awareness of the use of modern forms of payments and banking services by those attending high schools, primarily because no similar studies have been found. The gap in this respect prompted research to be undertaken into the level of use and awareness of the availability of modern forms of payment and banking services by high school students from Podkarpackie Voivodeship. Selected socio-demographic features characterised students. An assessment of the security level of these tools has been researched academically as well.

The article formulates the following research hypotheses:

- H1: The level of use of electronic banking tools depends on the socio-demographic characteristics of students (parents' education level).

- H2: The level of use of electronic wallets depends on the socio-demographic characteristics of students (gender of students).

- H3: The level of use of the bank's mobile application for making purchases on the internet depends on the socio-demographic characteristics of students (parents' education level).

- H4: The level of use of secure online payments depends on the socio-demographic characteristics of students (student's place of residence).

- H5: The assessment of the security of electronic transactions is correlated with the level of parents' education.

Literature review: the impact of socio-demographic characteristics

on the level of mobile payment usage among adults

The end of the 20th century brought significant changes to electronic banking. It became the leading way to communicate with a bank, and payments could be made online. The readiness of particular groups of customers to use specific tools, depending on their age, gender, income, or education level, was also investigated. 
At this point, it is essential to emphasise the characteristics of particular payment methods and banking services that appear in the article. They are listed in Table 1.

Table 1. Characteristics of individual forms of payment and banking services

\begin{tabular}{|l|l|}
\hline \multicolumn{1}{|c|}{ Concept } & \multicolumn{1}{c|}{ Definition } \\
\hline $\begin{array}{l}\text { Electronic purse } \\
\text { (e-wallet) }\end{array}$ & $\begin{array}{l}\text { The digital equivalent of a wallet in your pocket. From a technical } \\
\text { point of view, it is an account set up with an external company that } \\
\text { deals with online payments and allows you to carry out non-cash } \\
\text { transactions in real time }\end{array}$ \\
\hline Online payment & $\begin{array}{l}\text { Transfer service (so-called pay-by-link) consisting of full integration } \\
\text { of the payment process with the banking system. When finalising } \\
\text { the purchase, all transfer details are filled in automatically, and their } \\
\text { editing is locked }\end{array}$ \\
\hline Mobile banking & $\begin{array}{l}\text { Access to banking services thanks to a mobile application installed on } \\
\text { a phone or tablet }\end{array}$ \\
\hline Electronic banking & $\begin{array}{l}\text { Access to a bank account not only via a computer but also via } \\
\text { telephone, call centre, SMS, IVR, smartphone or POS terminal }\end{array}$ \\
\hline
\end{tabular}

Source: author based on Zarańska, Zborowski (2018), PayU (2020, 15 October), Kisiel (2016)

Many authors mention gender among the factors influencing the level of use of mobile payments. This applies mainly to men who use computers much more willingly than women (Bell, 1995; Kay, 1992), are more interested in computers, which in turn increases differences in the level of internet use (Shashaani, 1997), and use the internet itself more often (Ono, Zavodny, 2002; Teo, Lim, 2000). It has also been proven that men, unlike women, are much more willing to adopt mobile banking services due to a greater interest in technology (Chen, Wellman, 2004; Laukkanen, Pasanen, 2008; MacGregor, Vrazalic, 2005).

Among numerous studies, results were also found proving that the level of e-banking use is not related to gender (Gan et al., 2006; Seyal, Rahim, 2011). The reason for this contradiction in research results may include factors such as the varying methodology of individual studies, different target groups and others. Also, generational differences should not be forgotten, and in this case, they may contribute to the varying results. The research was carried out at a different time. Therefore the age groups differed significantly from one another.

In the case of education level, researchers generally agree that this factor influences the adoption and use of e-banking. The most common arguments were:

- those with higher education have more significant opportunities and computer skills (Kay, 1992),

- a relationship has been shown between higher education and the use of the internet in Chile (Mendoza, Toledo, 1997),

- there is a relationship between gender, education and having bank accounts in the Kurdistan Region of Iraq (Hamakhan, 2020),

- education shows a positive correlation with the use of computer techniques (Al-Jabri Al-Khaldi, 1997; Seyal, Rahim, Rahman, 2002),

- in Polish society, in the period from 2001 to 2016, the level of banking increased due to universal access to the internet and mobile banking services and education (Karczewski, 2019), 
- electronic banking acceptance depends on customers' education level, with better-educated customers more likely to adopt e-banking (Al-Ashban, Burney, 2001; Bucevska, V., Bucevska, J., 2013).

It is also no secret that age is related to the level of adoption of e-banking services and the perception of their benefits and risks. The vast majority of research has proved that age negatively correlates with the readiness to use modern banking services and the level of customer satisfaction. According to J. Munusamy, S. Chelliah, S. Annamalah (2013), there is a relationship between age and the use of e-banking with those up to 25 years of age comprising the leading group of electronic banking users.

A review of international literature, including the impact of age on levels of use of electronic banking tools, encourages research into young Polish customers to be expanded. It is to verify whether and to what extent they are aware of the availability of various forms of payments and banking services, to what extent they use them, and whether this is related to the socio-demographic characteristics of individual respondents.

The level of mobile payment usage by young people in Podkarpackie Voivodeship: research methodology and results

The research's primary subject was to determine the impact of high school students' socio-demographic characteristics on the level of use of modern forms of payment and banking services and assess these tools' level of security.

The survey was conducted in October and November 2019 among $326^{1}$ students from 10 high schools in Podkarpackie Voivodeship. The questionnaires were addressed to general and 'economic' high schools. The respondents took part in an educational project led by the author and completed the questionnaires during workshop meetings.

The questionnaire consisted of several dozen questions related to various financial and economic issues; however, only those questions relating to current payment services and banking instruments were selected for this article. The responses were based on a five-point Likert scale.

The obtained results were analysed according to criteria such as gender, parents' education and place of residence (Domański, Pruska, 2000; Ostasiewicz, 1999) and subjected to mathematical and statistical analyses using the Mann-Whitney U test and Spearman's rank correlation coefficient. Table 2 presents information about the respondents.

Most of the respondents (69.85\%) were female and lived in rural areas (71.69\%). Most of the students' parents from Podkarpackie Voivodeship had just secondary education: mothers (65.23\%), fathers (71.69\%).

The students were asked to what extent they are using:

- electronic banking,

- the bank's mobile application for making purchases on the internet,

- secure online payments (PayU, Blik and alike),

- electronic wallets (Paypal, Neteller, Skrill, Apple Pay, Google Pay, and alike).

${ }^{1}$ One questionnaire was rejected due to multiple missing data. 
Table 2. Information about the respondents

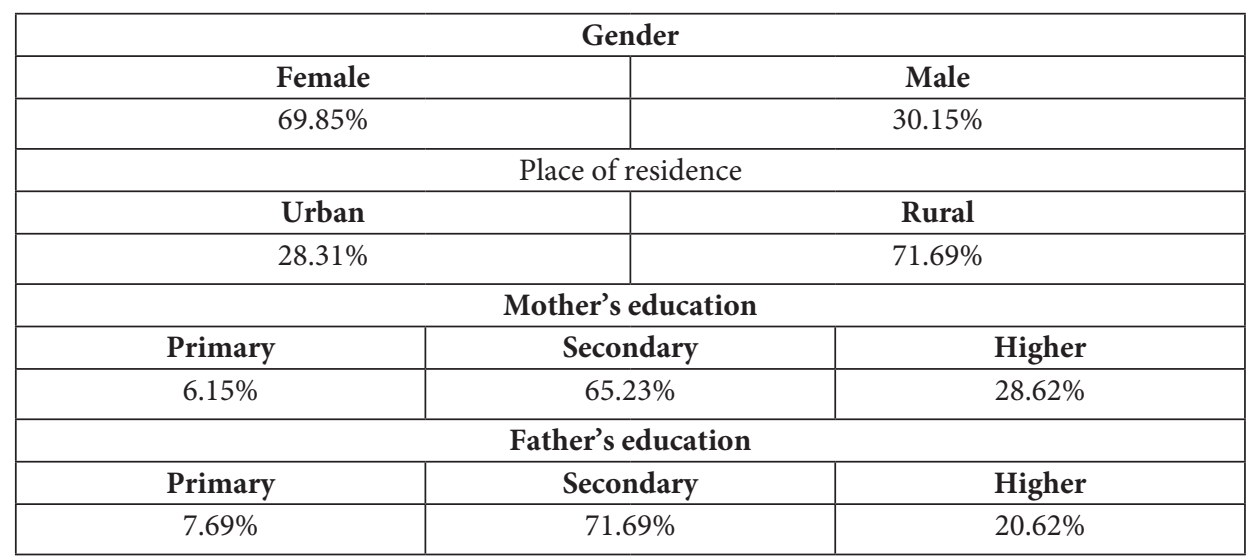

Source: author, n-325

Table 3 shows the statistically significant results.

Table 3. The relationship between selected socio-demographic characteristics of the surveyed respondents and the level of use of modern forms of payments and banking services

\begin{tabular}{|c|c|c|c|c|c|c|c|}
\hline \multirow{2}{*}{ Gender: } & \multirow{2}{*}{$\mathbf{n}$} & \multicolumn{6}{|c|}{$\begin{array}{l}\text { Compliance with the statement (scale 1-5): } \\
\text { I use electronic wallets }\end{array}$} \\
\hline & & $\mathbf{M}$ & Me & Min. & \multicolumn{2}{|c|}{ Max. } & $\begin{array}{l}\text { Sum } \\
\text { of ranks }\end{array}$ \\
\hline Woman & 227 & 2.42 & 2.00 & 1.00 & \multicolumn{2}{|c|}{5.00} & 33904.5 \\
\hline Man & 98 & 3.22 & 4.00 & 1.00 & \multicolumn{2}{|c|}{5.00} & 19070.5 \\
\hline In total & 325 & 2.66 & 2.00 & 1.00 & \multicolumn{2}{|c|}{5.00} & 52975.0 \\
\hline \multicolumn{2}{|c|}{ Statistical significance: } & \multicolumn{6}{|c|}{$\mathrm{Z}=4.13795, \mathrm{p}=0.000035$} \\
\hline \multirow{2}{*}{$\begin{array}{l}\text { Place of } \\
\text { residence: }\end{array}$} & \multirow[b]{2}{*}{$\mathbf{n}$} & \multicolumn{6}{|c|}{$\begin{array}{l}\text { Compliance with the statement (scale 1-5): } \\
\text { I use secure online payments }\end{array}$} \\
\hline & & M & Me & Min. & \multicolumn{2}{|c|}{ Max. } & $\begin{array}{c}\text { Sum of } \\
\text { ranks }\end{array}$ \\
\hline City & 92 & 3.40 & 4.00 & 1.00 & & & 17060.0 \\
\hline Village & 233 & 2.83 & 2.00 & 1.00 & & & 35915.0 \\
\hline In total & 325 & 2.99 & 2.00 & 1.00 & & & 52975.0 \\
\hline \multicolumn{2}{|c|}{ Statistical significance: } & \multicolumn{6}{|c|}{ 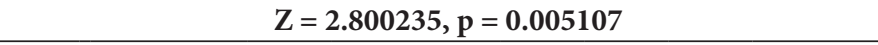 } \\
\hline \multirow{2}{*}{$\begin{array}{l}\text { Mother's } \\
\text { education: }\end{array}$} & \multirow[t]{2}{*}{$\mathbf{n}$} & \multicolumn{6}{|c|}{$\begin{array}{l}\text { Compliance with the statement (scale 1-5): } \\
\text { I use the bank's mobile application to make purchases on the internet }\end{array}$} \\
\hline & & M & \multicolumn{2}{|l|}{$\mathrm{Me}$} & & & SD \\
\hline Primary & 20 & 2.80 & 2.50 & & & & 1.64 \\
\hline Secondary & 212 & 3.17 & 4.00 & & & & 1.56 \\
\hline Higher & 93 & 3.51 & 4.00 & & & & 1.58 \\
\hline In total & 325 & 3.24 & 4.00 & & & & 1.58 \\
\hline Statistical si & ice: & & & $=0.12$ & & & \\
\hline
\end{tabular}


The influence of the socio-demographic characteristics of the young on mobile telephone...

\begin{tabular}{|c|c|c|c|c|c|c|}
\hline \multirow{2}{*}{$\begin{array}{l}\text { Mother's } \\
\text { education: }\end{array}$} & \multirow[t]{2}{*}{$\mathbf{n}$} & \multicolumn{5}{|c|}{$\begin{array}{l}\text { Compliance with the statement (scale 1-5): } \\
\text { I use electronic banking }\end{array}$} \\
\hline & & $\mathbf{M}$ & $\mathrm{Me}$ & Min. & Max. & SD \\
\hline Primary & 20 & 2.65 & 2.00 & 1.00 & 5.00 & 1.73 \\
\hline Secondary & 212 & 3.01 & 3.00 & 1.00 & 5.00 & 1.76 \\
\hline Higher & 93 & 3.87 & 5.00 & 1.00 & 5.00 & 1.51 \\
\hline In total & 325 & 3.24 & 4.00 & 1.00 & 5.00 & 1.74 \\
\hline \multicolumn{2}{|c|}{ Statistical significance: } & \multicolumn{5}{|c|}{$\mathrm{rs}=0.235234, \mathrm{p}=0.000018$} \\
\hline \multirow{2}{*}{$\begin{array}{l}\text { Father's } \\
\text { education: }\end{array}$} & \multirow[t]{2}{*}{$\mathbf{n}$} & \multicolumn{5}{|c|}{$\begin{array}{l}\text { Compliance with the statement (scale 1-5): } \\
\text { I use the bank's mobile application to make purchases on the internet }\end{array}$} \\
\hline & & $\mathbf{M}$ & $\mathrm{Me}$ & Min. & Max. & SD \\
\hline \begin{tabular}{|l|} 
Primary \\
\end{tabular} & 25 & 2.52 & 2.00 & 1.00 & 5.00 & 1.61 \\
\hline Secondary & 233 & 3.27 & 4.00 & 1.00 & 5.00 & 1.55 \\
\hline Higher & 67 & 3.42 & 4.00 & 1.00 & 5.00 & 1.62 \\
\hline In total & 325 & 3.24 & 4.00 & 1.00 & 5.00 & 1.58 \\
\hline \multicolumn{2}{|c|}{ Statistical significance: } & \multicolumn{5}{|c|}{$\mathrm{rs}=0.115024, \mathrm{p}=0.038216$} \\
\hline \multirow{2}{*}{$\begin{array}{l}\text { Father's } \\
\text { education: }\end{array}$} & \multirow[t]{2}{*}{$\mathbf{n}$} & \multicolumn{5}{|c|}{$\begin{array}{l}\text { Compliance with the statement (scale 1-5): } \\
\text { I use electronic banking }\end{array}$} \\
\hline & & M & $\mathrm{Me}$ & Min. & Max. & SD \\
\hline \begin{tabular}{|l|} 
Primary \\
\end{tabular} & 25 & 2.56 & 2.00 & 1.00 & 5.00 & 1.64 \\
\hline Secondary & 233 & 3.18 & 3.00 & 1.00 & 5.00 & 1.74 \\
\hline Higher & 67 & 3.70 & 5.00 & 1.00 & 5.00 & 1.67 \\
\hline In total & 325 & 3.24 & 4.00 & 1.00 & 5.00 & 1.74 \\
\hline \multicolumn{2}{|c|}{ Statistical significance: } & \multicolumn{5}{|c|}{$\mathrm{rs}=0.177138, \mathrm{p}=0.001344$} \\
\hline
\end{tabular}

Source: author, n-325

The Mann-Whitney U test result showed statistically significant $(\mathrm{p}<0.05)$ differences between the analysed groups. Male respondents used electronic wallets more often; on the other hand, secure online payments were more often used by urban residents.

The result of the Spearman's rank correlation coefficient showed that with an increase in the education level of mothers, the students in question more often used:

- the bank's mobile application to make purchases on the internet (correlation with a statistically weak impact),

- electronic banking (correlation with a statistically weak impact).

On the other hand, the result of the Spearman's rank correlation coefficient showed that with an increase in the education level of respondents' fathers, they more often used:

- the bank's mobile application to make purchases on the internet (correlation with a statistically weak impact),

- electronic banking (correlation with a statistically weak impact).

The above results allow for the positive verification of the first four hypotheses $(\mathrm{H} 1$, H2, H3, H4). To verify the last hypothesis, students were asked to assess the level of security in the use of electronic payments and mobile banking. Table 4 summarises the statistically significant results.

The result of the Mann-Whitney $U$ test showed statistically significant $(\mathrm{p}<0.05)$ differences between the analysed groups, with male respondents expressing higher ratings for the security of mobile banking and the security of electronic payments. 
In the case of the parents' education, the result of the Spearman's rank correlation coefficient showed that along with the increase in the level of education of mothers (H5), assessment of mobile banking security among students (statistically weak correlation) and the assessment of the safety of electronic payments increased (correlation with a statistically weak impact) increased.

Table 4. The relationship between selected socio-demographic characteristics of the surveyed respondents and the assessment of the security of modern forms of payments and banking services

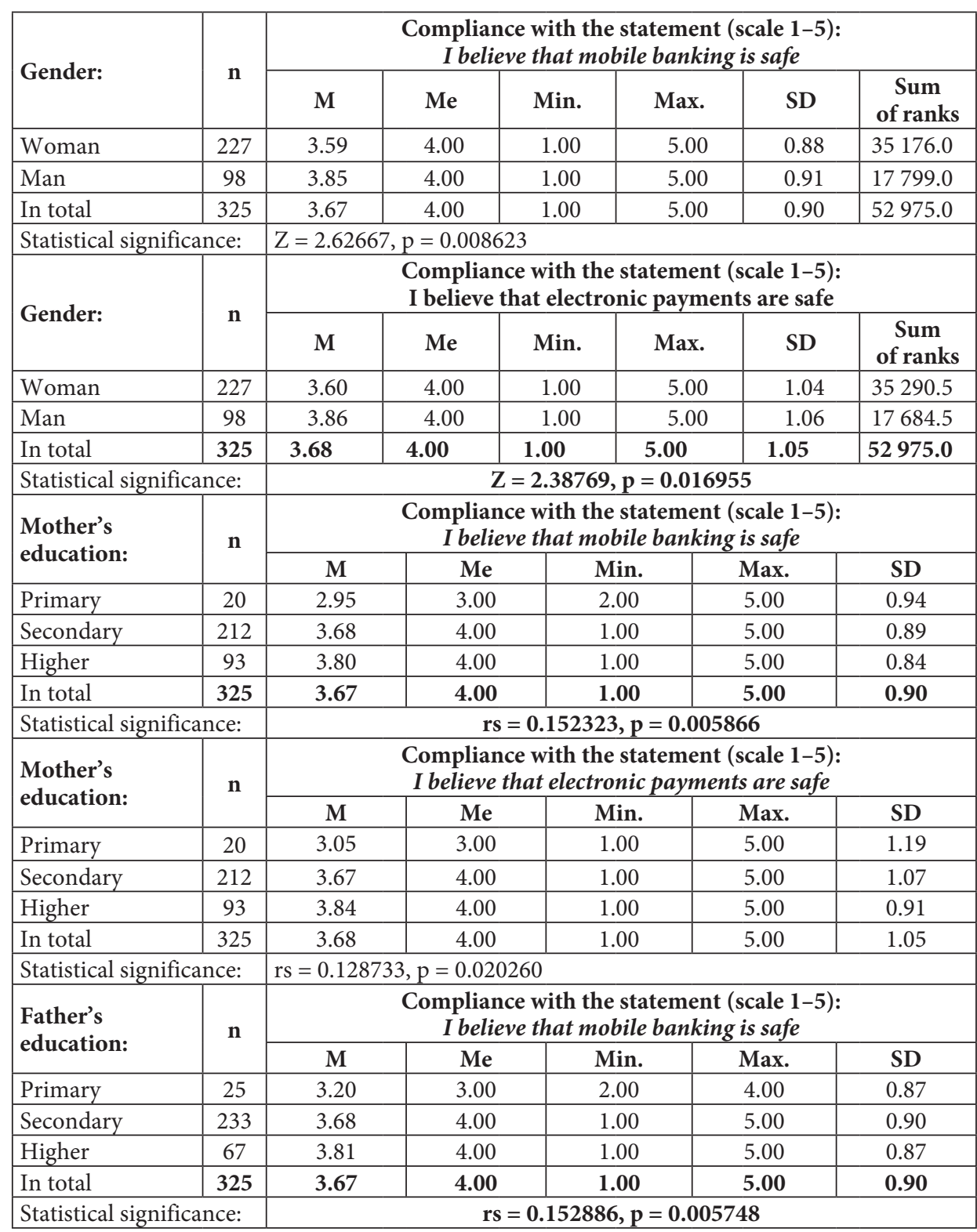

Source: author, n-325 
A similar relationship was noticed in the context of fathers' education in the case of which, along with the increase in the level of father's education (H5), the assessment of mobile banking security increased among the surveyed students (correlation with a statistically weak impact - the result of the Spearman's rank correlation coefficient).

The studied socio-demographic characteristics of high school students from Podkarpackie Voivodeship, gender, parents' education and place of residence impact the level of use of some modern forms of payments and banking services. It depends on the specific tools. The higher level of parental education translates into a higher assessment of mobile banking security and the security of electronic payments.

On this basis, it can be concluded that the hypotheses $(\mathrm{H} 1, \mathrm{H} 2, \mathrm{H} 3, \mathrm{H} 4, \mathrm{H} 5)$ have been positively verified.

\section{Conclusions}

The development of financial awareness in society, the availability and use of modern forms of payment and banking services, particularly among the young generation, are undoubtedly a topic that deserves extensive discussion.

The socio-demographic characteristics of the respondents, such as gender, parental education and place of residence, influenced the use of modern forms of payment and electronic banking services. An interesting fact is that students often did not fully realise what Blik or PayU payments were. It may indicate some degree of inattention when making these types of transactions, and students were only able to confirm that they use such services after seeing the logos.

The research confirmed the results of foreign analyses which show that men use electronic banking tools more often and more willingly. Additionally, research has shown that urban residents use secure online payments more often, which may be reflected in the greater availability of personal electronic banking tools in urban areas. Similarly, in the case of mothers and fathers' education levels, positive patterns in the family and the greater experience of parents mean their children have a greater knowledge of the use of secure online payments. They also use a bank's mobile applications for online shopping more willingly and evaluate electronic banking and electronic payments as more secure.

Positive verification of Podkarpackie Voivodeship hypotheses justifies research in other regions or on a more extensive research sample.

It is necessary to systematically increase Poles' financial knowledge by making them aware of the importance of the role of parents in shaping the level of use of electronic banking tools, and thus entrepreneurship among young people.

\section{References}

Ahmed, E.M., Phin, G.S. (2016). Factors Influencing the Adoption of Internet Banking in Malaysia. Journal of Internet Banking \& Commerce, 21(1), 1-28.

Al-Ashban, A.A., Burney, M.A. (2001). Customer Adoption of Tele-Banking Technology: The Case of Saudi Arabia. The International Journal of Bank Marketing, 19(4/5), 191-200.

Al-Jabri, M., Al-Khaldi, A.M. (1997). Effects of User Characteristics on Computer Attitudes among Undergraduate Business Students. Journal of End-User Computing, 9(2), 16-22.

Bell, M. (1995). The Impact of IT Education and Training, Computer Bulletin, BCS. 
Bucevska, V., Bucevska, J. (2013). An empirical analysis of factors affecting the adoption of electronic banking in Macedonia: a logit model. Advances in Business-Related Scientific Research Journal, 4(1), 27-37.

Business Insider Polska. (2019; 2020, 12 October). Co drugi Polak ma problem $z$ wiedza o finansach. Retrieved from: https://businessinsider.com.pl/twoje-pieniadze/budzet-domowy/wiedza-finansowa-polakow-badanie-marzec-2019/58k2r80

Business Insider Polska. (2018; 2020, 22 October). Polacy niewiele wiedza o finansach. Najgorzej jest $z$ pożyczkami $i$ debetami. Retrieved from: https://businessinsider.com.pl/twoje-pieniadze/ budzet-domowy/wiedza-finansowa-polakow-badanie-kapitalniorg-listopad-2018/pw75pwx

Chen, W., Wellman, B. (2004). The global digital divide-Within and between countries. IT and Society, $1(7), 39-45$.

Czarnecki, E. (2017). Wpływ czynników społeczno-ekonomicznych klientów na poziom korzystania z produktów i usług bankowości elektronicznej. Journal of Financial Management and Accounting, $5(3), 19-34$.

Domański, Cz., Pruska, K. (2000). Nieklasyczne metody statystyczne. Warszawa: Wydawnictwo PWE.

Gan, C., Clemes, M., Limsombunchai, V., Weng, A. (2006). A logit analysis of electronic banking in New Zealand. International Journal of Bank Marketing, 24(6), 360-383.

Hamakhan, Y.T.M. (2020). An Empirical Investigation of E-Banking in the Kurdistan Region of Iraq: the Moderating Effect of Attitude. E-Finanse, 16(1), 45-66.

Karczewski, P. (2019). Analiza poziomu ubankowienia społeczeństwa w Polsce w kontekście rozwoju bankowości internetowej i mobilnej. Zeszyty Naukowe Politechniki Częstochowskiej. Zarządzanie, $34,70-80$.

Karjaluoto, H., Mattila, M., Pento, T. (2002). Electronic Banking in Finland: Consumer Beliefs and Reactions to a New Delivery Channel. Journal of Financial Service Marketing, 6(4), 346-361.

Kay, R.H. (1992). Understanding Gender Difference in Computer Attitudes. Journal of Research on Computing Education, 25(2), 159-171.

Kisiel, M. (2011). Internet a konkurencyjność banków w Polsce. Warszawa: Wydawnictwo CeDeWu.

Kisiel, M. (2016; 2020, 18 October). Elektroniczny portfel przeżywa druga młodość. Dlaczego warto z niego korzystać?. Retrieved from: https://www.bankier.pl/wiadomosc/Elektroniczny-portfel-przezywadruga-mlodosc-Dlaczego-warto-Z-niego-korzystac-7483157.html

Laukkanen, T., Pasanen, M. (2008). Mobile banking innovators and early adopters: How they differ from other online users?. Journal of Financial Services Marketing, 13(2), 86-94.

MacGregor, R.C., Vrazalic, L. (2005). A basic model of electronic commerce adoption barriers: A study of regional businesses in Sweden and Australia. Journal of small business and enterprise development, 12(4), 510-527.

Mendoza, M.R.H., Toledo, J.A.A. (1997). Demographics and Behavior of the Chilean Internet Population. Journal of Computer-Mediated Communication, 3(1).

Munusamy, J., Chelliah, S., Annamalah, S. (2013). Demographic Factors and Adoption of Retail Internet Banking: An Experience in Malaysia. International Journal of Management \& Innovation, 5(2), $34-48$.

Ono, H., Zavodny, M. (2002). Gender and the Internet. SSE/EFI Working Paper Series in Economics and Finance, 495.

Ostasiewicz, W. (1999). Statystyczne metody analizy danych. Wrocław: Wydawnictwo AE im. Oskara Langego we Wrocławiu.

PayU. (2020, 15 October). Korzystaj z nowoczesnych rozwiązań płatniczych. Retrieved from: https:// www.payu.pl/metody-platnosci/przelew-internetowy

Salehi, M., Alipour, M. (2010). E-Banking in Emerging Economy: Empirical Evidence of Iran. International Journal of Economics and Finance, 2(1), 201-209.

Seyal, A.H., Rahim, Md.M. (2011). Customer Satisfaction with Internet Banking in Brunei Darussalam: Evaluating the Role of Demographic Factors. e-Service Journal, 7(3), 47-68. 
Seyal, A.H., Rahim, Md.M., Rahman, M.N. (2002). A Study of Computer Attitudes of NonComputing Students of Technical Colleges in Brunei Darussalam. Journal of End-User Computing, 14(2), $40-47$.

Shashaani, L. (1997). Gender Difference in Computer Attitudes and Use among College Students. Journal of Educational Research in Computing, 16(1), 27-51.

Teo, T.S.H., Lim, V.K.G. (2000). Gender differences in Internet Usage and Task Preferences. Behaviour and Information Technology, 19(4), 283-295.

Zarańska, K., Zborowski, M. (2018). Charakterystyka bankowości elektronicznej. In: A. Gospodarowicz (ed.), Bankowość elektroniczna. Istota i innowacje. Warszawa: C.H. Beck

Magdalena Wiercioch, $\mathrm{PhD}$, assistant professor at the Institute of Economics and Finance (Department of Finance and Accounting) at the University of Rzeszów. Her research interests focus on corporate finances and the use of public aid funds in the broadest sense. She has gained professional experience in international corporations in finance, accounting and tax departments. Besides, she has managed educational projects aimed at primary and secondary school students, is the author of a financial blog and is interested in promoting knowledge and financial education, especially among women, children and the young.

ORCID: https://orcid.org/0000-0002-6091-917X

\section{Address:}

Uniwersytet Rzeszowski

Kolegium Nauk Społecznych

Instytut Ekonomii i Finansów

ul. Ćwiklińnkiej 2

35-601 Rzeszów, Polska

e-mail: magdalena.wiercioch@ur.edu.pl 